\title{
Calcified Intracranial Hydatid Cyst: Case Report
}

\section{Kalsifiye İntrakraniyal Kist Hidatik: Olgu Sunumu}

\author{
Ender Köktekir ${ }^{1}$, Yavuz Erdem², Cevdet Gökçek², Mete Karatay², Ali Yılmaz², \\ Mehmet Akif Bayar², Sua Sümer ${ }^{3}$
}

'Department of Neurosurgery, Faculty of Medicine, Selçuk University, Konya, Turkey

2Department of Neurosurgery, Ministry of Health Ankara Training and Research Hospital, Ankara, Turkey

${ }^{3}$ Department of Infectious Diseases, Faculty of Medicine, Selçuk University, Konya, Turkey

\begin{abstract}
We present a 26-year-old patient who did farming related work had an asymptomatic intracranial hydatid cyst. A calcified intracranial cystic mass was found on radiological investigations and the patient underwent surgery. The mass was totally excised. The histopathology result reported a hydatid cyst. There were no postoperative complications. Calcification is quite rare in cerebral hydatid cyst. The computed tomography and magnetic resonance imaging provide information that is especially useful for preoperative diagnosis. Observing membrane detachment and daughter cysts during these investigations is pathognomonic. The presence of calcification in the cyst wall and intracystic membranes indicated hydatid cyst (Turkiye Parazitol Derg 2011; 35: 220-3)
\end{abstract}

Key Words: Calcification, Hydatid cyst, Intracranial cyst

Received: 21.02 .2011

Accepted: 04.08.2011

\section{ÖZET}

Bu çalışmada; 26 yaşında, çiftlik işleri ile uğraşan, asemptomatik intrakraniyal hidatik kisti olan bir olgu sunulmaktadır. Kafa travması nedeni ile yapılan radyolojik incelemelerde kalsifiye intrakraniyal hidatik kist saptanan hasta cerrahi tedavi ile kitlenin tamamen çıkartılması sonrası nörolojik defisiti olmadan taburcu edildi. İntrakraniyal hidatik kistlerin kalsifikasyonu oldukça nadirdir. Bilgisayarlı beyin tomografisi ve kraniyal magnetik rezonans incelemeleri operasyon öncesi tanı için oldukça önemlidir. Radyolojik incelemeler esnasında membran detaşmanının, kist duvarında kalsifikasyonun ve kist içi membranların varlığı hidatik kist varlığına işaret eder. (Turkiye Parazitol Derg 2011; 35: 220-3)

Anahtar Sözcükler: Kireçlenme, Hidatik kist, İntrakranial kist

Geliş Tarihi: 21.02.2011

Kabul Tarihi: 04.08.2011

\section{INTRODUCTION}

Hydatid disease is caused by the larval stage of the Echinococcus granulosus and is endemic in various regions of the world. The prevalance is higher in North Africa and Mediterranean countries such as Turkey, Greece and some regions of Spain and Italy and it ranges between $1-150 / 100.000(1,2)$. The most common localization of the disease is the liver and lung. The intracranial involvement incidence of the cyst if $1-4 \%$, while $1-5 \%$ of these cases show calcification (2-5). When intracranial involvement occurs, it is most commonly seen in the parietal and frontal areas, respectively. The diagnosis is usually made with clinical findings, imaging techniques and serologic tests $(2,6)$. We present a case of calcified hydatid cyst which was discovered incidentally.

Address for Correspondence / Yazışma Adresi: Dr. Ender Köktekir, Department of Neurosurgery, Faculty of Medicine, Selçuk University, Konya, Turkey Phone: +90 3322415000 E-mail: enderkoktekirnrs@hotmail.com doi:10.5152/tpd.2011.56 


\section{CASE REPORT}

A 26-year-old male patient who did farming-related work presented at our clinic with headache following a minor head trauma. The physical and neurological examinations were normal. The $x$-ray showed a left frontal calcified lesion (Figure 1). There was a $6 \times 5 \mathrm{~cm}$ mass with homogeneous peripheral calcification in the left frontal region on cranial computed tomography (CT) (Figure 2). Magnetic resonance imaging (MRI) showed the mass to contain membranous structures and to be hyperintense. There was no perilesional edema area and no contrast enhancement (Figure 3a, b). The patient was operated on via a left frontotemporal craniotomy. The mass was strongly adherent to the dura and it was therefore opened circularly, leaving this part on the mass. The mass ruptured while being dissected from the surrounding cerebral tissue and a large amount of yellow-brown material that was tviscous in character drained out. The ventricle was opened while the posterior section was being dissected and cerebrospinal fluid (CSF) was seen to come out. The mass was totally excised. There were no postoperative complications. The pathology result was hydatid cyst (Figure 4). Serological results including enzyme-linked immunoabsorbant assay (ELISA) test and indirect hemagglutination (IHA) test were negative and no other lesion was found on abdominal and thorax investigations. Culture of the cyst content sent during surgery did not grow anything. The patient was discharged on the $14^{\text {th }}$ postoperative day.

\section{DISCUSSION}

Hydatid cyst involves the liver in $75 \%$ of the patients, the lung in $15 \%$ and other organs in $10 \%(6,7)$. Central nervous system involvement is seen in $1 \%$ of the cases and is usually diagnosed in childhood. It can be located in any area of the brain but is most commonly seen at the area supplied by the middle cerebral artery in both hemispheres (most commonly in the parietal region, followed by the frontal region) (7-9). They are not symptomatic until they reach a certain size. There is usually no other focus, as in our case. Hepatic or pulmonary localization has been shown in only $10-20 \%$ of cerebral hydatid cysts $(9,10)$.

The epidemiologic and clinical findings, imaging techniques and serologic tests are used to make a diagnosis $(9,11)$. The serologic diagnosis of hydatid cyst usually is more of a challenge in the brain than in the other organs because the antibody response is usually absent or very low in the case of intracranial hydatid cyst, especially if calcified (12). In the presented case, the serologic tests including ELISA and IHA were negative but the imaging tests were specific for an intracranial calcified hydatid cyst.

CT shows cranial hydatid cysts as intraparenchymal, homogenous cystic lesions with distinct borders. The cyst fluid is isodense with the CSF and the cyst itself is usually circular. Noncontrast CT shows an isodense or hyperdense cyst wall compared to the brain tissue. The perilesional edema and contrast enhancement seen with abscesses or cystic tumors are unusual for hydatid cysts (7). MRI produces a similar radiological appearance. T1- and T2-weighted images show a low signal intensity rim of the cyst wall, while the cyst content is isointense with the CSF. There is mild or moderate perilesional edema in infected hydatid cysts and there may be limited contrast enhancement in the capsule region $(13,14)$. Membrane detachment and daughter cyst are pathognomonic findings on CT and MRI. The presence of calcification in the cyst wall and intracystic membranes indicate a hydatid cyst $(13,14)$. We found calcification both on

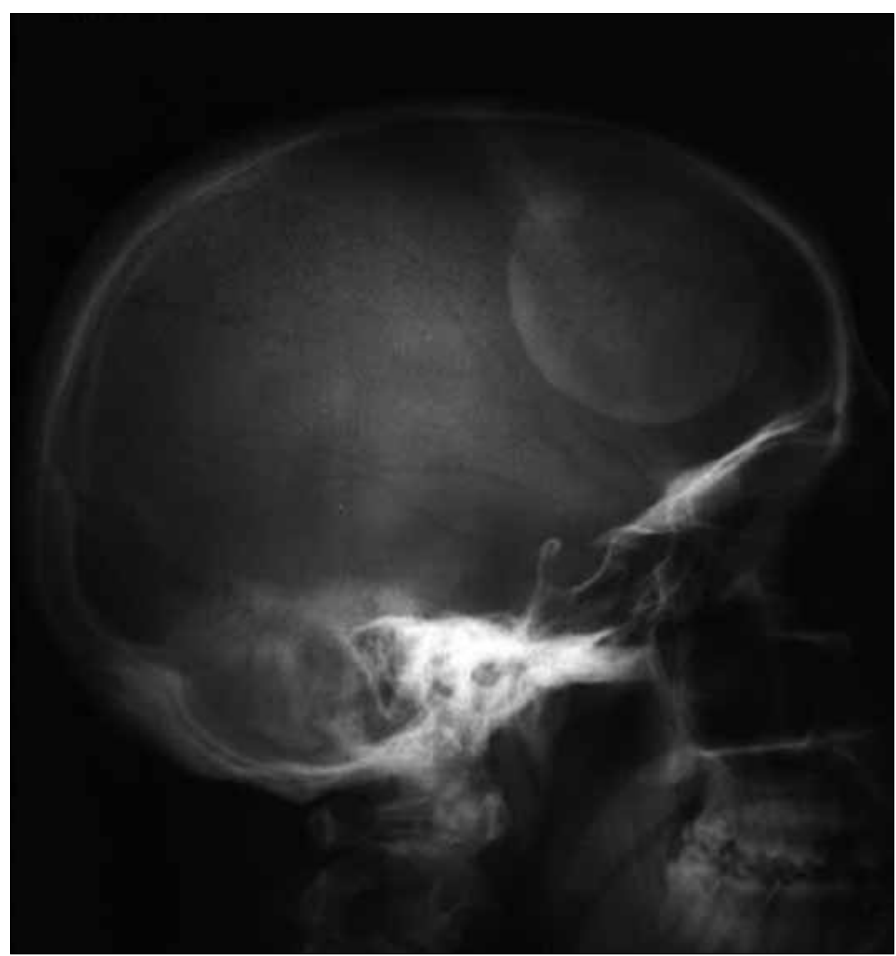

Figure 1. Calcified mass in the frontal region on direct cranial x-ray

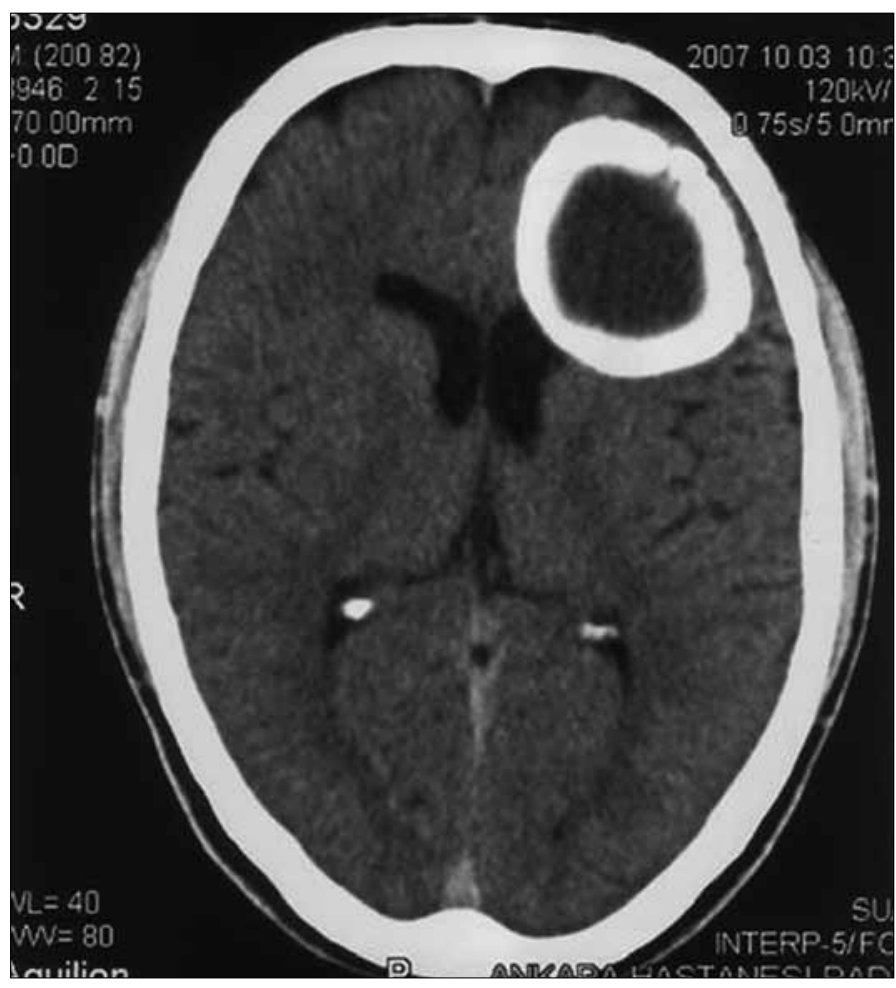

Figure 2. $6 \times 5 \mathrm{~cm}$ left frontal mass with perilesional calcification on CT 

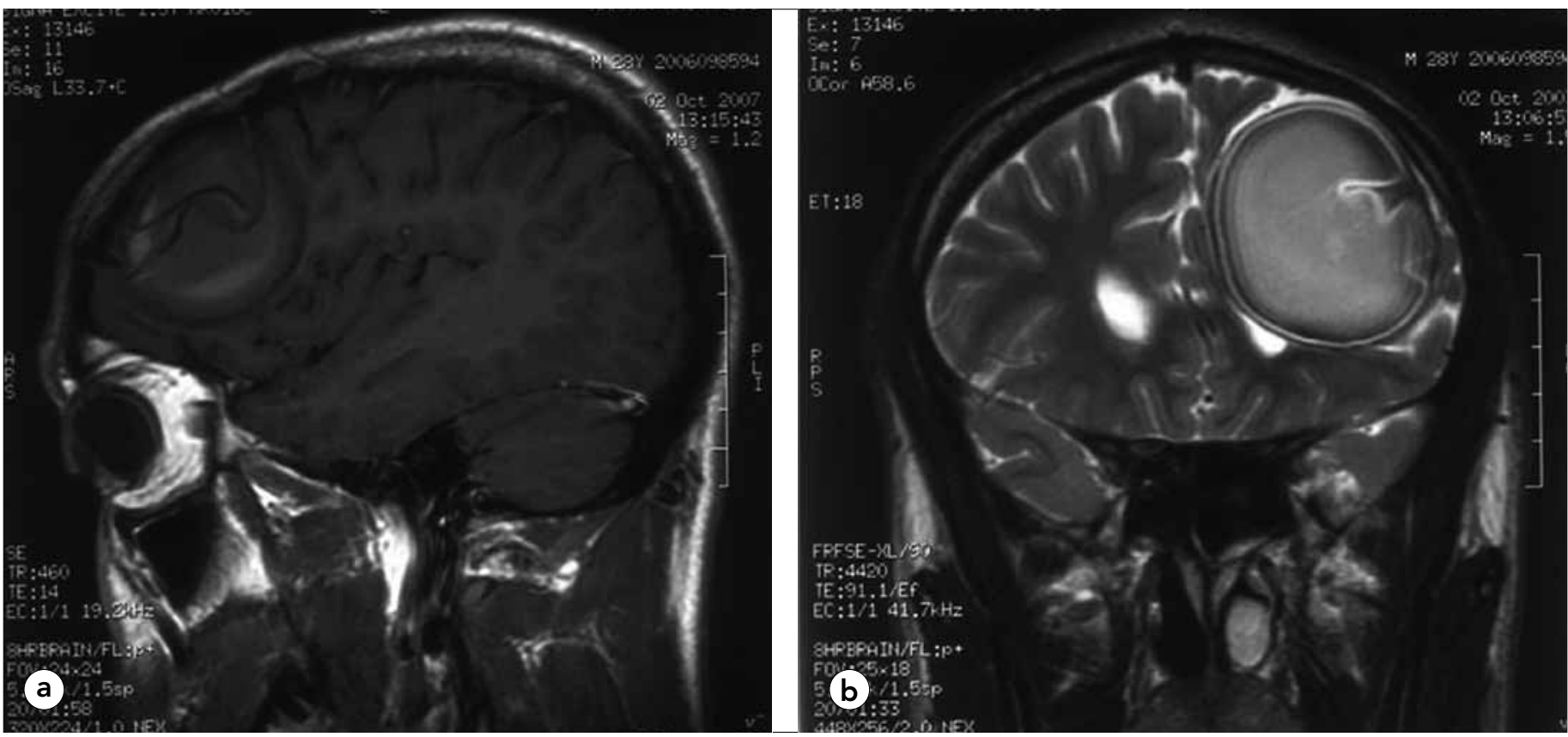

Figure 3. a) T1-weighted sagittal MRI shows intracystic membranes and b) T2-weighted coronal MRI shows membrane detachment

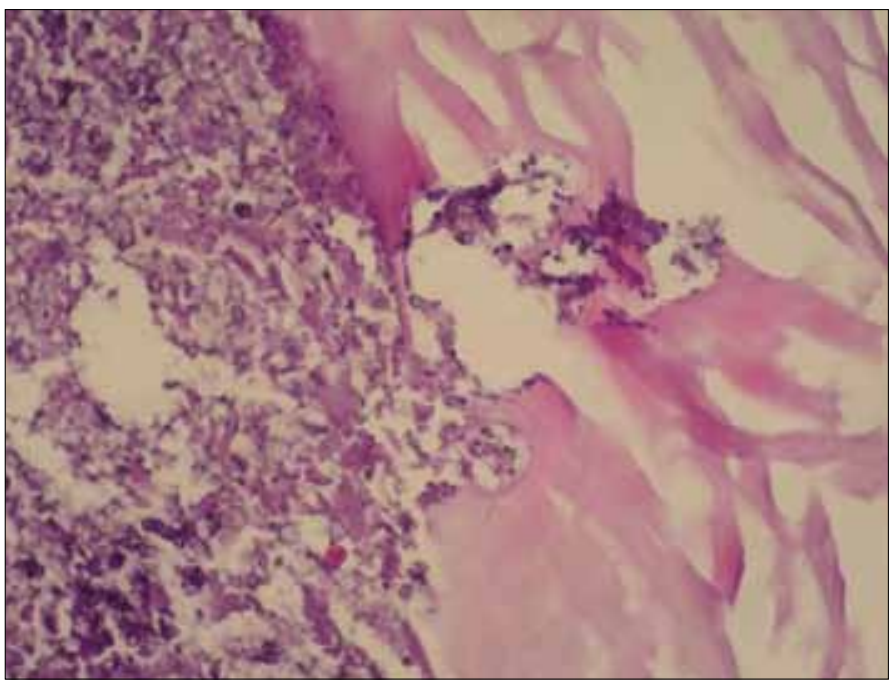

Figure 4. Degenerated and necrotic material calcified in some areas and cuticula. H\&E $\times 400$

direct cranial X-ray and CT in our case. MRI showed membrane detachment and intracystic membranes.

The incidence of calcification in hydatid cyst is $20-30 \%$ for liver localization and $1-5 \%$ for lung or liver localization $(6,7)$. The calcification is usually ring-like with a curvilinear pattern and develops in the pericyst consisting of modified host cells with a fibrous protective zone several $\mathrm{mm}$ thick. The hydatid cyst capsule consists of 3 layers with the pericysts outside, laminated membrane in the middle and germinal layer inside (15). The laminated membrane is a structure that lets nutrients pass through but stops bacteria. Damage to this membrane predisposes to infection. Calcification develops in all components of the cyst during the natural healing stage once the pericyst is calcified. The clear fluid that fills the cyst is replaced by a thick and viscous sub- stance rich in cholesterol as in our case. Finding calcification in the pericyts does not indicate death of the parasite. Although an association has been found between pericyst calcification and cyst inactivation for hydatid cysts localized in the liver, such a classification is not available for cerebral cysts due to the low number of cases $(6,16)$. Complete calcification indicates death of the parasite (15).

The primarily treatment of intracranial hydatid cysts is surgical. One of the aims of treatment for hydatid cysts located in the liver is calcification of the cyst. Surgical or medical treatment is therefore accepted to be contraindicated in the case of partial or total calcification in the cyst (6). A 'wait and see' approach is recommended before any surgical intervention for hydatid cysts with homogeneous calcification in the walls and those localized in the liver (6). There is no data on whether the same approach can be used for intracranial cysts. Cases of calcified hydatid cyst in the literature have almost all presented with epileptic seizures and this approach may therefore not be appropriate for intracranial hydatid cysts $(4,5,17-20)$.

In conclusion, a hydatid cyst should be considered in patients living in or coming from areas with endemic hydatid cyst disease, especially when calcification is found during radiological investigations and a membrane or detached membrane is seen inside the cyst.

\section{Conflict of Interest}

No conflict of interest was declared by the authors.

\section{REFERENCES}

1. Dakkak A. Echinococcus/hydatidosis: a severe threat in Mediterranean countries. Vet Parasitol 2010; 174: 2-11. [CrossRef]

2. Delibaş SB, Ozkoç S, Sahin S, Aksoy U, Akisü C. Evaluation of patients presenting with a suspicion of cystic echinococcosis to the serology laboratory of the Parasitology Department of Dokuz Eylül University Medical Faculty. Turkiye Parazitol Dergisi 2006; 30: 279-81. 
3. Alvarez F, Blazquez MG, Oliver B, Manrique M. Calcified cerebral hydatid cyst. Surg Neurol 1982; 17: 163-4. [CrossRef]

4. Abderrahmen K, Aouidj ML, Kallel J, Khaldi MM. Calcified cerebral hydatid cyst. Neurochirurgie 2007; 53: 371-4.

5. Bouaziz M. Calcified cerebral hydatid cyst: a case report. 2005; 15: 129-32.

6. Pawłowski ZS, Eckert J, Vuitton DA, Amman RW, Kern P, Craig PS, et al. Echinococcosis in humans: clinical aspects, diagnosis and treatment. WHO/OIE Manual on Echinococcosis in Humans and Animals: a Public Health Problem of Global Concern 2001. pp. 20-68.

7. Pedrosa I, Saiz A, Arrazola J, Ferreiros J, Pedrosa CS. Hydatid disease: radiologic and pathologic features and complications. Radiographics 2000; 20: 795-817.

8. Gökalp HZ, Dinçer C, Şekerci Z, Birler K. Cranial hydatid cysts. (Turkish) Türk Nöroşirurji Derg 1989; 2: 65-71.

9. Turgut M. Intracranial hydatidosis in Turkey: its clinical presentation, diagnostic studies, surgical management, and outcome. A review of 276 cases. Neurosurg Rev 2001; 24: 200-8. [CrossRef]

10. Singounas EG, Leventis AS, Sakas DE, Hadley DM, Lampadarios DA, Karvounis PC. Successful treatment of intracerebral hydatid cyst with albendazole: case report and review of the literature. Neurosurgery 1992; 31: 571-4. [CrossRef]

11. Yılmaz GR, Babur C. Ekinokokkosis tanısı. Türk Hij Den Biyol Derg 2007; 64: 35-44
12. Esgin $M, A k t a s ~ M, C o s k u n ~ S$. The investigation of antibody presence in the sera of patients with a suspicion of cystic echinococcosis by using indirect hemaglutination test (IHA). Turkiye Parazitol Derg 2007; 31: 283-7.

13. Bükte $Y$, Kemaloglu $S$, Nazaroglu H, Ozkan U, Ceviz A, Simsek M. Cerebral hydatid disease: CT and MR imaging findings. Swiss Med Wkly 2004; 134: 459-67.

14. El-Shamam O, Amer T, El-Atta MA. Magnetic resonance imaging of simple and infected hydatid cysts of the brain. Magn Reson Imaging 2001; 19: 965-74. [CrossRef]

15. Beggs I. The radiology of hydatid disease. AJR Am J Roentgenol 1985; 145: 639-48.

16. WHO Informal Working Group. International classification of ultrasound images in cystic echinococcosis for application in clinical and field epidemiological settings. Acta Trop 2003; 85: 253-61. [CrossRef]

17. Choukri M, Bertal A, Lakhdar A, Achouri M, Ouboukhlik A, el Kamar $A$, et al. Calcified cerebral hydatid cyst. Report of a case. J Neuroradiol 2001; 28: 261-3.

18. Menkü A, Kurtsoy A, Tücer B, Durak AC, Akdemir H. Calcified cerebral hydatid cyst following head trauma: case report. Turk Neurosurg 2004; 14: 36-40.

19. Micheli F, Lehkuniec E, Giannaula R, Caputi E, Paradiso G. Calcified cerebral hydatid cyst. Eur Neurol 1987; 27: 1-4. [CrossRef]

20. Yolaş C, Gündoğdu C, Yakut C: Dead cerebral cyst hydatid. A case report. (Turkish) Türk Nöroşirürji Derg 1993; 3: 38-40. 